\title{
NUTRIENT REMOVAL FROM SWINE WASTEWATER IN A COMBINED VERTICAL AND HORIZONTAL FLOW CONSTRUCTED WETLAND SYSTEM
}

\author{
Regina B. Vilas Bôas ${ }^{1 *}$, Ronaldo Fia ${ }^{2}$, Fátima R. L. Fia ${ }^{2}$, Alessandro T. Campos ${ }^{2}$, \\ Gabriela R. de Souza ${ }^{2}$
}

1*Corresponding author. Universidade Federal de Lavras/Lavras - MG, Brasil. E-mail: regina_lavras@yahoo.com.br

\section{KEYWORDS}

Cynodon spp., phosphorus, nitrogen, post-treatment, Typha sp.

\begin{abstract}
This study aimed to assess the performance of a combined vertical flow (VFCW) and horizontal subsurface-flow (HFCW) constructed wetland systems built on a pilot scale and submitted to different configurations and organic load application rates of pre-treated swine wastewater (SWW) in anaerobic systems on the nitrogen and phosphorus removal. The average values of redox potential in the systems were between anoxic and aerobic conditions, favoring an increased nitrate concentration in VFCW. Nitrogen removal by VFCW-HFCW system can be considered as satisfactory, reaching removal values of $75 \%$. VFCW and HFCW proved to be limited in phosphorus removal, reaching values of $48 \%$.
\end{abstract}

\section{INTRODUCTION}

In order to minimize the potential impacts caused by the intensive swine farming, researches have been developed to improve systems for treating swine wastewater. These systems have prioritized organic matter removal, which has a direct effect on environmental quality. Swine wastewater is also rich in nutrients, especially nitrogen and phosphorus. Nitrogen and phosphorus are nutrients of a great importance to the food chain and when discharged in high concentrations in surface waters, they cause an enrichment of this environment, a phenomenon known as eutrophication (Barreto et al., 2013). Thus, the improvement of techniques of removing these pollutants is necessary.

Different types of constructed wetland (CW) systems are combined to achieve a greater efficiency in the post-treatment of wastewater, especially for nitrogen removal. Horizontal flow constructed wetland (HFCW) systems are widely used as a secondary treatment and promote satisfactory removal of BOD and suspended solids. However, there is a growing interest in obtaining a greater removal of nitrogenous compounds from wastewater, which has not been achieved only using HFCW due to its limited capacity of oxygen transfer, a characteristic of these systems. On the other hand, vertical flow constructed wetland (VFCW) systems provide good conditions for nitrification, but denitrification does not occur in these systems. Thus, hybrid or combined systems, in which the advantages of each system type are combined, have been studied, allowing producing waste water with a reduced organic load and lower nitrogen concentrations (Mendonça et al., 2015; Fia et al., 2017).

This study aimed to assess the performance of combined constructed wetland systems (vertical and horizontal flow) cultivated with Tifton 85 (Cynodon spp.) and cattail (Typha sp.) and submitted to different configurations and organic load application rates of pretreated swine wastewater in anaerobic systems on the nitrogen and phosphorus removal.

\section{MATERIAL AND METHODS}

The experiment was conducted in the wastewater treatment area of the Department of Animal Science, but under the responsibility of the Department of Engineering, at the Federal University of Lavras, Lavras, MG, Brazil. The geographical coordinates of the area are $21^{\circ} 14^{\prime} \mathrm{S}$ and $42^{\circ} 00^{\prime} \mathrm{W}$, with an average altitude of $918 \mathrm{~m}$ and regional climate Cwa according to Köppen classification.

Currently, swine wastewater (SWW) is submitted to a pre-treatment consisting of a static sieve and primary/secondary treatment composed of a compartmentalized anaerobic reactor (CAR) followed by a upflow anaerobic sludge blanket (UASB) reactor and decanter (Pereira et al., 2011). Thus, SWW used in this study was that from the existing treatment system.

The experiment was composed of constructed wetland systems, three of vertical flow (VFCW) cultivated with Tifton 85 (Cynodon spp.), followed by three of

\footnotetext{
${ }^{2}$ Universidade Federal de Lavras/ Lavras - MG, Brasil.

Received in: 8-21-2017

Accepted in: 3-5-2018
} 
horizontal subsurface-flow (HFCW) cultivated with cattail (Typha sp.). Each HFCW received, individually and by gravity, the wastewater from each VFCW. VFCWs were composed of fiberglass boxes with a total volume of 100 $\mathrm{L}, 0.54 \mathrm{~m}$ of height, and $0.86 \mathrm{~m}$ of average diameter filled with gravel \#0 (average initial void volume of $0.494 \mathrm{~m}^{3}$ $\mathrm{m}^{-3}$ ). HFCWs, on the other hand, were composed of fiberglass boxes with dimensions of $2.0 \times 0.5 \times 0.60 \mathrm{~m}$ (length $\times$ width $\times$ height) and filled with gravel \#0 (average initial void volume of $0.494 \mathrm{~m}^{3} \mathrm{~m}^{-3}$ ) to a height of $0.55 \mathrm{~m}$ and a water level maintained $0.05 \mathrm{~m}$ below the support material surface.

In order to assess the influence of the hydrodynamic behavior on pollutant removal, especially as nitrogen, HFCWs were built with three different configurations (Figure 1): (1) with internal partitions fixed to HFCW sides to favor a piston-type flow from one side to another inside the HFCW; (2) with internal partitions fixed above and below the HFCW bed to favor upward and downward flow inside the HFCW, allowing mixing the wastewater sometimes in a strictly anaerobic environment (HFCW bottom) and sometimes in an aerobic/anoxic environment (HFCW surface); and (3) without internal partitions, as in traditionally researched HFCWs.

The experiment consisted of 3 phases $(80,60$, and 60 days of duration), with a gradual increase of surface application rates (SAR) (Table 1) of organic matter and nutrients and a continuous inflow. The differentiation in SAR was performed by the inflow variation to VFCWs, performed by means of a solenoid-dosing pump. HFCW feeding was conducted by gravity from VFCWs. The theoretical hydraulic detention time (HDT) was 4.8, 3.1, and 2.3 days respectively for phases I, II, and III in HFCWs. HDT of VFCWs was not quantified. A hydraulic rate of 108, 164, and $222 \mathrm{~mm} \mathrm{~d}^{-1}$ was applied in VFCWs for the three experimental phases, respectively.

We determined the variables $\mathrm{pH}\left(4.500-\mathrm{H}^{+}\right)$and redox potential $(2.580-\mathrm{Eh})$ by potentiometry in the inflow and outflow of the systems, the concentrations of total Kjeldahl nitrogen (TKN) by Kjeldahl semi-micro method (4.500-Norg $\mathrm{C})$, nitrite $\left(\mathrm{NO}_{2}^{-}\right)$by colorimetric method (4.500- $\left.\mathrm{NO}_{2}{ }^{-} \mathrm{B}\right)$, total phosphorus (TP) by vanado molibo phosphoric acid method (4.500-PC) (APHA, AWWA \& WEF, 2012), and nitrate $\left(\mathrm{NO}_{3}{ }^{-}\right)$by salicylate colorimetric method (MATOS, 2012) in order to analyze their behavior over time and in each phase.

(1)

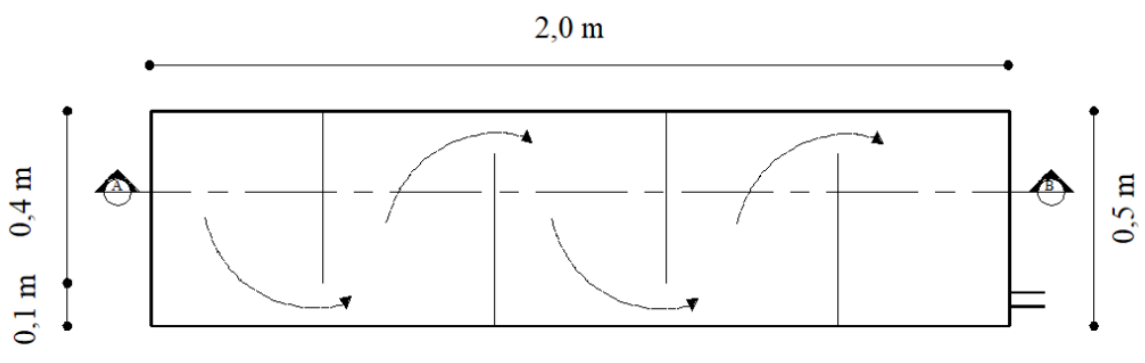

Floor plan - HFCW1

(2)

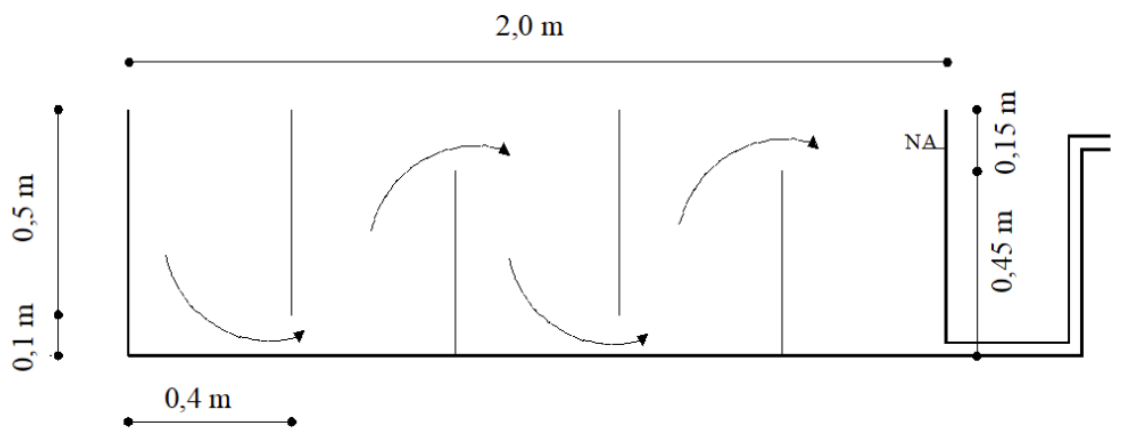

Section AB - HFCW2

(3)

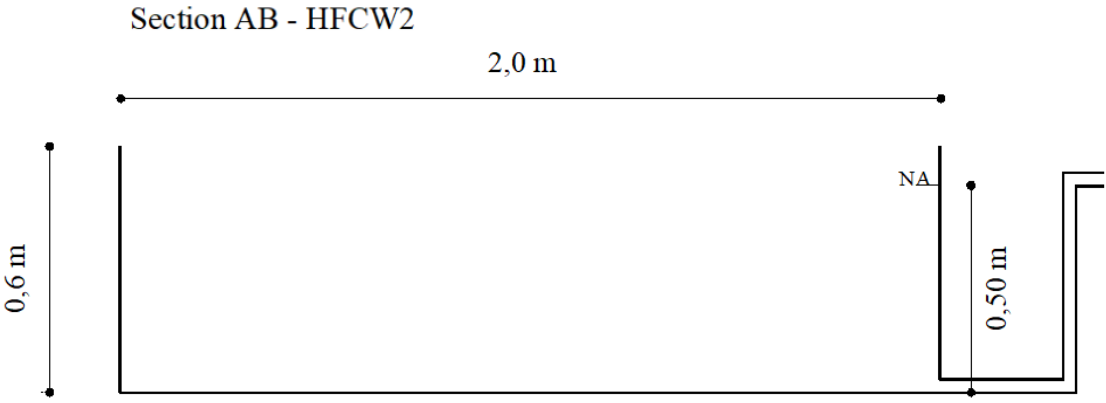

Section AB - HFCW3

FIGURE 1. Scheme of different HFCW configurations used in the treatment of swine wastewater: (1) floor plan of HFCW1; (2) cross-section of HFCW2; and (3) cross-section of HFCW3. 
TABLE 1. Average values of surface application rates (SAR) of the vertical (VFCW) and horizontal (HFCW) constructed wetland systems in each phase.

\begin{tabular}{|c|c|c|c|c|c|c|c|c|c|}
\hline \multirow{2}{*}{ System } & \multicolumn{3}{|c|}{ Phase I } & \multicolumn{3}{|c|}{ Phase II } & \multicolumn{3}{|c|}{ Phase III } \\
\hline & $\mathrm{SAR}_{\mathrm{COD}}{ }^{(13)}$ & $\mathrm{SAR}_{\mathrm{TKN}}{ }^{(12)}$ & $\mathrm{SAR}_{\mathrm{TP}}{ }^{(11)}$ & SAR $_{\mathrm{COD}^{(9)}}$ & SAR $_{\text {TKN }}{ }^{(9)}$ & $\mathrm{SAR}_{\mathrm{TP}}{ }^{(9)}$ & SAR $_{\mathrm{COD}}{ }^{(8)}$ & SAR $_{\text {TKN }^{(8)}}$ & $\mathrm{SAR}_{\mathrm{TP}}{ }^{(8)}$ \\
\hline VFCW1 & 763 & 324 & 22.9 & 828 & 203 & 21.6 & 1,032 & 316 & 30.9 \\
\hline VFCW2 & 754 & 321 & 22.5 & 830 & 204 & 21.6 & 1,032 & 316 & 30.9 \\
\hline VFCW3 & 754 & 324 & 22.9 & 828 & 203 & 21.6 & 1,032 & 316 & 30.9 \\
\hline HFCW1 & 294 & 125 & 8.8 & 319 & 78 & 8.3 & 397 & 121 & 11.9 \\
\hline HFCW2 & 290 & 124 & 8.7 & 320 & 78 & 8.3 & 397 & 121 & 11.9 \\
\hline HFCW3 & 290 & 124 & 8.7 & 319 & 78 & 8.3 & 397 & 121 & 11.9 \\
\hline
\end{tabular}

SARTKN-surface application rate of Kjeldahl total nitrogen $\left(\mathrm{kg} \mathrm{ha}^{-1} \mathrm{~d}^{-1}\right.$ of TKN); SARTP-surface application rate of total phosphorus $\left(\mathrm{kg}_{\mathrm{T}} \mathrm{ha}^{-1}\right.$ $\mathrm{d}^{-1}$ of TP). In parentheses is the number of samples taken.

For VFCWs, an analysis of variance was performed followed by the Tukey's test at 5\% probability level when a significant effect of factors was observed. For statistical analysis, a completely randomized design with three replications (three VFCWs) and three phases were considered. For HFCWs and for joint systems (VFCWHFCW1, VFCW-HFCW2, and VFCW-HFCW3), an analysis of variance was performed followed by the Tukey's test at $5 \%$ probability level when a significant effect of factors was observed. A $3 \times 3$ factorial scheme $(3$ HFCWs and 3 phases) with the number of repetitions over time was used according to the number of samples of each variable. Statistical analyses were performed by using the SISVAR ${ }^{\circledR}$ Statistical Program (Ferreira, 2011).

\section{RESULTS AND DISCUSSION}

The $\mathrm{pH}$ variation in the inflow through the systems was relatively small (Table 2 ), with a value close to neutrality, which probably did not influence microorganism performance and, consequently, nutrient removal. For the conventional denitrification process, the ideal $\mathrm{pH}$ value is around 7.5 (Xinshan et al., 2010), as observed in our study.

Although SWW was derived from an anaerobic treatment and hence had to present negative values of Eh, the observed positive values can be justified by its pumping to a storage box, where a growth of algae responsible for the environment oxygenation was observed.

TABLE 2. Average values and standard deviation of $\mathrm{pH}$, redox potential (Eh), total $\mathrm{Kjeldahl}$ nitrogen $(\mathrm{TKN})$, nitrate $\left(\mathrm{NO}_{3}{ }^{-}\right)$, nitrite $\left(\mathrm{NO}_{2}^{-}\right)$, and total phosphorus (TP) obtained in the inflow and outflow of each system during the three operation phases.

\begin{tabular}{|c|c|c|c|c|c|c|c|}
\hline \multirow{2}{*}{ Variables } & Inflow & VFCW1 & VFCW2 & VFCW3 & HFCW1 & HFCW2 & HFCW3 \\
\hline & \multicolumn{7}{|c|}{ Phase I } \\
\hline $\mathrm{pH}^{(13)}$ & $8.1 \pm 0.4$ & $7.9 \pm 0.3$ & $7.9 \pm 0.3$ & $7.7 \pm 0.3$ & $8.0 \pm 0.2$ & $8.0 \pm 0.2$ & $7.9 \pm 0.2$ \\
\hline $\mathrm{Eh}(\mathrm{mV})^{(10)}$ & $87 \pm 20$ & $100 \pm 13$ & $100 \pm 11$ & $101 \pm 11$ & $91 \pm 13$ & $92 \pm 13$ & $93 \pm 14$ \\
\hline $\mathrm{TKN}\left(\mathrm{mg} \mathrm{L}^{-1} \text { of N}\right)^{(12)}$ & $196 \pm 48$ & $100 \pm 49$ & $116 \pm 55$ & $112 \pm 57$ & $74 \pm 34$ & $91 \pm 33$ & $74 \pm 32$ \\
\hline $\mathrm{NO}_{3}^{-}\left(\mu \mathrm{g} \mathrm{L}^{-1} \text { of } \mathrm{N}\right)^{(12)}$ & $2.9 \pm 5.1$ & $21.9 \pm 15.8$ & $20.8 \pm 16.6$ & $21.7 \pm 18.3$ & $26.3 \pm 20.2$ & $25.7 \pm 18.4$ & $29.3 \pm 20.9$ \\
\hline $\mathrm{NO}_{2}^{-}\left(\mu \mathrm{g} \mathrm{L}^{-1} \text { of } \mathrm{N}\right)^{(12)}$ & $0.2 \pm 0.3$ & $65.4 \pm 22.3$ & $60.4 \pm 26.8$ & $75.4 \pm 20.9$ & $48.4 \pm 24.0$ & $60.1 \pm 17.6$ & $66.6 \pm 20.9$ \\
\hline \multirow[t]{2}{*}{$\mathrm{TP}\left(\mathrm{mg} \mathrm{L}^{-1} \text { of } \mathrm{P}\right)^{(11)}$} & $13.3 \pm 9.5$ & $17.5 \pm 14.4$ & $13.0 \pm 10.1$ & $13.5 \pm 11.8$ & $10.9 \pm 9.5$ & $12.9 \pm 9.4$ & $12.7 \pm 9.5$ \\
\hline & \multicolumn{7}{|c|}{ Phase II } \\
\hline $\mathrm{pH}^{(9)}$ & $8.0 \pm 0.3$ & $7.2 \pm 0.5$ & $7.3 \pm 0.3$ & $7.4 \pm 0.3$ & $6.9 \pm 0.6$ & $7.3 \pm 0.4$ & $7.3 \pm 0.4$ \\
\hline $\mathrm{Eh}(\mathrm{mV})^{(9)}$ & $78 \pm 30$ & $107 \pm 28$ & $109 \pm 28$ & $106 \pm 29$ & $115 \pm 29$ & $108 \pm 28$ & $110 \pm 30$ \\
\hline TKN (mg L L of N) $)^{(9)}$ & $82 \pm 65$ & $47 \pm 43$ & $44 \pm 38$ & $53 \pm 41$ & $43 \pm 33$ & $37 \pm 26$ & $42 \pm 38$ \\
\hline $\mathrm{NO}_{3}^{-}\left(\mu \mathrm{g} \mathrm{L}^{-1} \text { of } \mathrm{N}\right)^{(9)}$ & $2.0 \pm 1.6$ & $26.9 \pm 13.3$ & $24.1 \pm 10.7$ & $20.0 \pm 7.8$ & $20.7 \pm 10.7$ & $19.2 \pm 7.8$ & $20.1 \pm 8.4$ \\
\hline $\mathrm{NO}_{2}^{-}\left(\mu \mathrm{g} \mathrm{L}^{-1} \text { of } \mathrm{N}\right)^{(9)}$ & $0.8 \pm 0.7$ & $4.9 \pm 7.5$ & $9.0 \pm 12.5$ & $8.5 \pm 13.6$ & $1.5 \pm 3.7$ & $2.9 \pm 8.4$ & $3.2 \pm 9.2$ \\
\hline \multirow[t]{2}{*}{$\mathrm{TP}\left(\mathrm{mg} \mathrm{L}^{-1} \text { of } \mathrm{P}\right)^{(9)}$} & $8.7 \pm 5.3$ & $9.3 \pm 5.7$ & $10.0 \pm 5.2$ & $9.5 \pm 6.0$ & $8.9 \pm 6.0$ & $8.3 \pm 4.2$ & $9.1 \pm 4.3$ \\
\hline & \multicolumn{7}{|c|}{ Phase III } \\
\hline $\mathrm{pH}^{(8)}$ & $7.8 \pm 0.3$ & $7.3 \pm 0.2$ & $7.3 \pm 0.2$ & $7.2 \pm 0.3$ & $7.0 \pm 0.4$ & $7.0 \pm 0.3$ & $6.9 \pm 0.4$ \\
\hline $\mathrm{Eh}(\mathrm{mV})^{(8)}$ & $103 \pm 22$ & $113 \pm 17$ & $111 \pm 17$ & $108 \pm 21$ & $118 \pm 30$ & $118 \pm 15$ & $125 \pm 29$ \\
\hline TKN (mg L L of N) $)^{(8)}$ & $94 \pm 53$ & $54 \pm 31$ & $52 \pm 33$ & $36 \pm 19$ & $25 \pm 20$ & $25 \pm 20$ & $19 \pm 14$ \\
\hline $\mathrm{NO}_{3}^{-}\left(\mu \mathrm{g} \mathrm{L}^{-1} \text { of } \mathrm{N}\right)^{(8)}$ & $0.9 \pm 0.6$ & $28.3 \pm 15.2$ & $28.0 \pm 14.8$ & $30.1 \pm 15.0$ & $16.2 \pm 15.1$ & $16.6 \pm 15.4$ & $17.2 \pm 16.5$ \\
\hline $\mathrm{NO}_{2}^{-}\left(\mu \mathrm{g} \mathrm{L}^{-1} \text { of } \mathrm{N}\right)^{(8)}$ & $0.2 \pm 0.3$ & $4.3 \pm 3.2$ & $5.1 \pm 4.2$ & $4.9 \pm 3.1$ & $0.20 \pm 0.3$ & $0.1 \pm 0.1$ & $0.0 \pm 0.0$ \\
\hline $\mathrm{TP}\left(\mathrm{mg} \mathrm{L}^{-1} \text { of } \mathrm{P}\right)^{(8)}$ & $9.2 \pm 8.9$ & $5.6 \pm 3.3$ & $8.5 \pm 9.9$ & $5.5 \pm 5.8$ & $6.6 \pm 5.0$ & $5.9 \pm 7.6$ & $6.6 \pm 8.1$ \\
\hline
\end{tabular}

Eh in $\mathrm{mV}$; TKN in $\mathrm{mg} \mathrm{L}^{-1}$ of $\mathrm{N}$; $\mathrm{NO}_{3}^{-}$in $\mathrm{mg} \mathrm{L}^{-1}$ of N; $\mathrm{NO}_{2}^{-}$in $\mu \mathrm{g} \mathrm{L}^{-1}$ of $\mathrm{N}$; $\mathrm{TP}$ in $\mathrm{mg} \mathrm{L}^{-1}$. In parentheses is the number of samples taken. 
The outflow of VFCWs presented higher values of Eh during the first phase when compared to the values observed in the outflow of HFCWs. Probably a lower amount of organic matter applied in the systems associated to the water percolation movement through the support material provided favorable conditions to the maintenance of higher dissolved oxygen levels in the environment and, consequently, higher values of Eh. In general, the observed redox conditions were between anoxic $(-100 \mathrm{mV}<\mathrm{Eh}$ $<100 \mathrm{mV}$ ) and aerobic (Eh> $100 \mathrm{mV}$ ) (Matos et al., 2010a).

From the second phase, even with an increase in flow rate and the consequent increase of turbulence in the environment, no significant reduction ( $p>0.05)$ was observed in the average values of redox potential (Eh) in VFCWs. In the HFCW outflows, we observed, in some moments, similar values of Eh and, in others, an increase in its average values, which is probably due to a greater development of the planted cattail in the system (Matos et al., 2010a). In addition, Tifton 85 does not present aerenchym a in its structure, which may have hampered the air insertion by the plants and reduced Eh values in VFCWs. In this sense, Matos et al. (2010a) observed higher Eh values in an HFCW cultivated with cattail when compared to another cultivated with Tifton 85 .

Inflow concentrations of TKN were relatively high (Table 2), which demonstrates the limited capacity of anaerobic systems to remove nitrogen. However, Amorim et al. (2015) observed nitrogen removal of the order of $30 \%\left(22.9 \mathrm{~g} \mathrm{~d}^{-1}\right)$ in an upward flow anaerobic reactor when treating swine wastewater.
In addition, nitrate and nitrite formation were observed in VFCWs (Table 2) since these systems are more oxygenated, leading to a higher oxidation of $\mathrm{NH}_{4}{ }^{+}$into nitrite and nitrate (Xinshan et al., 2010). In phases II and III, the higher flow rate may have caused a higher atmospheric air drag and, consequently, promoted a greater atmospheric oxygen entry into the system (Gaboutloeloe et al., 2009; Abdelhakeem et al., 2016), resulting in a higher oxidation of nitrite into nitrate. In phase III, we observed a decrease in the outflow values of TKN and nitrite and an increase between 5 and $50 \%$ in nitrate concentrations in VFCW outflows. Nevertheless, the average TKN removal did not change significantly (p>0.05) (Table 3). A satisfactory efficiency of TKN removal was obtained for all systems in the three operation phases, with values higher than those observed by Sarmento et al. (2012) when treating swine wastewater in VFCWs (28 to 37\%) and a removal of $17 \%$ observed by Vymazal \& Kröpfelová (2011) in the initial two months of VFCW monitoring in the domestic sewage treatment.

During the first phase, probably the lower contribution of organic matter in HFCWs may have favored the conversion of ammoniacal forms of nitrogen into nitrate, increasing its concentration, since the organic matter competes for a reduced oxygen concentration in the environment. In the third phase, a greater denitrification capacity (15 to 27\%) was observed in HFCWs, with higher percentages of nitrite and nitrate removal $(\mathrm{p}<0.05)$ and TKN, except for HFCW3 (Table 4), resulting in lower average concentrations of nitrite and nitrate in the outflow (HFCWs) when compared to the inflow.

TABLE 3. Average values of Kjeldahl total nitrogen (TKN) removal in the vertical (VFCWs), horizontal (HFCWs), and vertical-horizontal (VFCWs-HFCWs) systems in different phases of system operation.

\begin{tabular}{|c|c|c|c|c|c|c|c|c|c|}
\hline Phase & VFCW1 & VFCW2 & VFCW3 & HFCW1 & HFCW2 & HFCW3 & $\begin{array}{l}\text { VFCW- } \\
\text { HFCW1 }\end{array}$ & $\begin{array}{l}\text { VFCW- } \\
\text { HFCW2 }\end{array}$ & $\begin{array}{l}\text { VFCW- } \\
\text { HFCW3 }\end{array}$ \\
\hline I & $52 \mathrm{aA}$ & $40 \mathrm{aA}$ & $44 \mathrm{aAB}$ & $24 \mathrm{aA}$ & $22 \mathrm{aA}$ & $31 \mathrm{aA}$ & $61 \mathrm{aAB}$ & $53 \mathrm{aA}$ & $64 \mathrm{aAB}$ \\
\hline II & $47 \mathrm{aA}$ & $45 \mathrm{aA}$ & $31 \mathrm{aA}$ & $26 \mathrm{aA}$ & $25 \mathrm{aA}$ & $32 \mathrm{aA}$ & $44 \mathrm{aA}$ & $49 \mathrm{aA}$ & $46 \mathrm{aA}$ \\
\hline III & $41 \mathrm{aA}$ & $45 \mathrm{aA}$ & $58 \mathrm{aB}$ & $58 \mathrm{aB}$ & $54 \mathrm{aB}$ & $44 \mathrm{aA}$ & $75 \mathrm{aB}$ & $75 \mathrm{aB}$ & $76 \mathrm{aB}$ \\
\hline
\end{tabular}

Means followed by the same lowercase letter in the row within each configuration, i.e. vertical (VFCW), horizontal (HFCW) or global (VFCW - HFCW), do not differ from each other by Tukey's test at 5\% probability. For the same system, means followed by the same uppercase letter in the column do not differ from each other by the Tukey's test at $5 \%$ probability.

TABLE 4. Average values $(\%)$ of nitrite $\left(\mathrm{NO}_{2}{ }^{-}\right)$and nitrate $\left(\mathrm{NO}_{3}{ }^{-}\right)$removal in the horizontal systems (HFCW) in different phases of system operation.

\begin{tabular}{|c|c|c|c|c|c|c|}
\hline \multirow{2}{*}{ Phase } & \multicolumn{3}{|c|}{$\mathrm{NO}_{2}^{-}$} & \multicolumn{3}{|c|}{$\mathrm{NO}_{3}^{-}$} \\
\hline & HFCW1 & HFCW2 & HFCW3 & HFCW1 & HFCW2 & HFCW3 \\
\hline I & $31 \mathrm{aA}$ & $16 \mathrm{bA}$ & $18 \mathrm{bA}$ & $13 \mathrm{aA}$ & $8 \mathrm{aA}$ & $10 \mathrm{aA}$ \\
\hline II & $75 \mathrm{aB}$ & $89 b B$ & $89 b B$ & $32 \mathrm{aAB}$ & $26 \mathrm{aAB}$ & $24 \mathrm{aAB}$ \\
\hline III & $98 \mathrm{aC}$ & $99 \mathrm{aC}$ & $99 \mathrm{aC}$ & $46 \mathrm{aB}$ & $48 \mathrm{aB}$ & $35 \mathrm{aB}$ \\
\hline
\end{tabular}

For the same variable, means followed by the same lowercase letter in the row do not differ from each other by the Tukey's test at $5 \%$ probability. For the same system, means followed by the same uppercase letter in the column do not differ from each other by the Tukey's test at $5 \%$ probability. 
Vymazal \& Kröpfelová (2011) obtained on average $73 \%$ of total nitrogen removal after using two VFCWs followed by an HFCW during 2 years of monitoring. This result is similar to that observed in our study in the third phase $(75 \%)$. The average outflow concentration of ammonium and nitrate decreased from 25 to $6.7 \mathrm{mg} \mathrm{L}^{-1}$.

The different configurations of HFCWs did not significantly influence $(p>0.05)$ their performance in removing the different forms of nitrogen (Tables 3 and 4) for each assessed phase. An increase in the efficiency of TKN removal was observed for HFCWs as the applied load increased, especially in the systems HFCW1 and HFCW2 ( $p<0.05)$.

Despite the decreased TKN values in the wastewater, note that only the conversion of NTK into nitrite and nitrate does not mean a nitrogen removal, but only its conversion and continuity of the pollutant potential of wastewater when it is released in the environment. Thus, the effective nitrogen removal is the nitrite and nitrate removal from HFCWs (Table 4), being probably converted into $\mathrm{N}_{2}$. Moreover, part of TKN is incorporated into the sludge and absorbed by the crop.

In Brazil, Matos et al. (2010b) obtained 51 and 64\% of total nitrogen removal from swine wastewater treated in HFCWs cultivated with cattail and Tifton 85 , respectively, with no nitrification process previously installed. For these systems, 46 and $56 \%$ of ammonium removal were obtained. A total of $93 \mathrm{~kg} \mathrm{ha}^{-1} \mathrm{~d}^{-1}$ of total nitrogen and 67 $\mathrm{kg} \mathrm{ha}^{-1} \mathrm{~d}^{-1}$ of ammonium were applied, which is lower than the loads applied in our study.

TABLE 5. Average values of total phosphorus (TP) removal in the vertical (VFCW), horizontal (HFCW), and verticalhorizontal (VFCW-HFCW) systems in different phases of system operation.

\begin{tabular}{|c|c|c|c|c|c|c|c|c|c|}
\hline Phase & VFCW1 & VFCW2 & VFCW3 & HFCW1 & HFCW2 & HFCW3 & $\begin{array}{l}\text { VFCW- } \\
\text { HFCW1 }\end{array}$ & $\begin{array}{l}\text { VFCW- } \\
\text { HFCW2 }\end{array}$ & $\begin{array}{l}\text { VFCW- } \\
\text { HFCW3 }\end{array}$ \\
\hline I & $15 \mathrm{aA}$ & $15 \mathrm{aA}$ & $11 \mathrm{aA}$ & $35 \mathrm{aB}$ & $12 \mathrm{aA}$ & $13 \mathrm{aA}$ & $23 \mathrm{aA}$ & $19 \mathrm{aA}$ & $19 \mathrm{aAB}$ \\
\hline II & $18 \mathrm{aA}$ & $9 \mathrm{aA}$ & $11 \mathrm{aA}$ & $17 \mathrm{aA}$ & $17 \mathrm{aA}$ & $14 \mathrm{aA}$ & $18 \mathrm{aA}$ & $15 \mathrm{aA}$ & $5 \mathrm{aA}$ \\
\hline III & $31 \mathrm{aB}$ & $18 \mathrm{aA}$ & $43 \mathrm{bB}$ & $11 \mathrm{aA}$ & $39 \mathrm{aB}$ & $15 \mathrm{aA}$ & $32 \mathrm{aA}$ & $48 \mathrm{aB}$ & $37 \mathrm{aB}$ \\
\hline
\end{tabular}

Means followed by the same lowercase letter in the row within each configuration, i.e. vertical (VFCW), horizontal (HFCW) or global (VFCW-HFCW), do not differ from each other by Tukey's test at 5\% probability. For the same system, means followed by the same uppercase letter in the column do not differ from each other by the Tukey's test at $5 \%$ probability.

The hydrodynamic characteristic presented by HFCW2, when increasing the flow rate in phase III, may have favored solid retention in the system and hence phosphorus removal. When studying swine wastewater in HFCWs cultivated with cattail and Tifton 85, Matos et al. (2010b) obtained 85,29 , and $34 \%$ of phosphorus removal by applying about $20 \mathrm{~kg} \mathrm{ha}^{-1} \mathrm{~d}^{-1}$ of P. These authors observed removals of suspended solids of the order of $90 \%$, which is directly related to TP removal.

Satisfactory average removal efficiencies were observed for VFCW-HFCW in phase III. However, only VFCW-HFCW2 was significantly different from the others $(\mathrm{p}<0.05)$ in this phase (Table 5). Thus, the highest contribution to phosphorus removal in the joint system was given by HFCW, both by plant absorption and accumulation in the sludge formed in the system.
The joint removal of TKN by vertical and horizontal systems (VFCW-HFCW) (Table 4) was considered as satisfactory. In a literature review, Vymazal (2007) reported nitrogen removal efficiencies between 40 and $55 \%$ when loads between 6.8 and $17 \mathrm{~kg} \mathrm{ha}^{-1} \mathrm{~d}^{-1}$ of nitrogen (calculated) were applied in different configurations of vertical and horizontal constructed wetlands. These loads are much lower when compared to those applied in our study (Table 1), proving the good efficiencies observed here.

Higher nitrogen removal efficiencies may not have been achieved due to carbon reduction in the environment, quantified using COD (data not shown). Thus, higher efficiencies can be obtained by recirculating the outflows from $\mathrm{CWs}$ with a higher nitrate concentration in the anaerobic systems that precede them, such as UASB reactors. Gaboutloeloe et al. (2009), Xinshan et al. (2010), and Vymazal \& Kröpfelová (2011) also observed this result.

During phase III, a greater efficiency $(\mathrm{p}<0.05)$ in phosphorus removal was observed in CWs over time (Table 5), except for HFCW2. Wang et al. (2009) observed that CWs cultivated with Phragmites and Typha were able to remove on average $98 \%$ of the $33 \mathrm{mg} \mathrm{L}^{-1}$ of the phosphorus applied to the system from sewage sludge. These authors cited that other studies with similar loads were able to remove only 30 to $40 \%$ and efficiencies never exceeded $60 \%$. With an increase in phosphorus contribution in phase III, only HFCW2 improved the removal efficiency $(\mathrm{p}<0.05)$, HFCW3 maintained a similar efficiency of the other phases, and HFCW1 reduced the removal efficiency (Table 5). 


\section{CONCLUSIONS}

Based on the results, we concluded:

1. The $\mathrm{pH}$ values over the three monitoring phases remained close to neutrality, favoring microbial activity of organic matter degradation and nutrient conversion.

2. Nitrification was observed in VFCWs as the organic load and applied nutrients increased.

3. HFCWs were able to remove up to $58 \%$ of the TKN applied in the systems and $35-48 \%$ of nitrate in phase III.

4. The different system configurations did not influence nitrification/denitrification capacity of the treated wastewater $(\mathrm{p}>0.05)$

5. Vertical and horizontal constructed wetland systems showed to be limited regarding phosphorus removal, ranging from 18 to $43 \%$ in the first ones, with a statistical difference for VFCW2 (18\%), and from 11 to $39 \%$ in the second ones, with a statistical difference for HFCW2 $(39 \%)(\mathrm{p}<0.05)$.

6. TKN and TP removal by the joint vertical and horizontal systems (VFCW-HFCW) can be considered as satisfactory, reaching values of 75 and $48 \%$ of removal in phase III, respectively.

\section{ACKNOWLEDGMENTS}

The authors are grateful to the Fundação de Amparo à Pesquisa do Estado de Minas Gerais (FAPEMIG) and the National Council for Scientific and Technological Development $(\mathrm{CNPq})$ for the financial support and/or scholarships for Scientific Initiation.

\section{REFERENCES}

Abdelhakeem SG, Aboulroos SA, Kame MM (2016) Performance of a vertical subsurface flow constructed wetland under different operational conditions. Journal of Advanced Research 7:803-814.

Amorim F, Fia R, Silva JRM, Chaves CFM, Pasqualin PP (2015) Unidades combinadas RAFA-SAC para tratamento de água residuária de suinocultura - parte II Nutrientes. Engenharia Agrícola 35(5):931-940.

APHA - American Public Health Association; AWWA American Water Works Association; WEF - Water Environment Federation. Standard methods for the examination of water and wastewater. (2012) Washington, APHA/AWWA/WEF, 22 ed.

Barreto LV, Barros FM, Bonomo P, Rocha FA, Amorim J da S (2013) Eutrofização em rios brasileiros. Enciclopédia Biosfera, Centro Científico Conhecer 9(16):2165-2179.

Debusk TA, Grace KA, Dierberg FE, Jackson SD, Chimney MJ, Gu B (2004) An investigation of the limits of phosphorus removal in wetlands: a mesocosm study of a shallow periphyton-dominated treatment system.

Ecological Engineering 23(1):1-14.
Ferreira DF (2011) Sisvar: a computer statistical analysis system. Revista Brasileira Ciência e Agrotecnologia 35(6):1039-1042.

Fia FRL, Matos AT de, Fia R, Borges AC, Cecon PR (2017) Efeito da vegetação em sistemas alagados construídos para tratar águas residuárias da suinocultura. Engenharia Sanitária Ambiental 22(2):303-311.

Gaboutloeloe GK, Chen S, Barber ME, Stöckle CO (2009) Combinations of horizontal and vertical flow constructed wetlands to improve nitrogen removal. Water, Air, Soil Pollution Focus 9:279-286.

Matos AT (2012) Qualidade do meio físico ambiental. Viçosa, UFV. 150p.

Matos AT, Freitas WS, Brasil MS, Borges AC (2010a) Influência da espécie vegetal cultivada nas condições redox de sistemas alagados construídos. Engenharia Agrícola 30:518-526.

Matos AT, Freitas WS, Lo Monaco PAV (2010b) Eficiência de sistemas alagados construídos na remoção de poluentes de águas residuárias da suinocultura. Revista Ambiente \& Água 5:119-132.

Mendonça HV de, Ribeiro CB de M, Borges AC, Bastos RR (2015) Sistemas Alagados Construídos em Batelada: remoção de Demanda Bioquímica de Oxigênio e regulação de $\mathrm{pH}$ no tratamento de efluentes de laticínios. Revista Ambiente \& Água 10(2):442-453. DOI: http://dx.doi.org/10.4136/ambi-agua.1511

Pereira EL, Campos CMM, Moterani F, Oliveira Neto AM (2011) Eficiência de um sistema de reatores anaeróbios no tratamento de efluentes líquidos de suinocultura. Acta Scientiarum Technology 33:287-293.

Sarmento AP, Borges AC, Matos AT (2012) Evaluation of vertical-flow constructed wetlands for swine wastewater treatment. Water Air Soil Pollut 223:1065-1071.

Vymazal J (2007) Removal of nutrients in various types of constructed wetlands. Science of the Total Environment 380:48-65.

Vymazal J, Kröpfelová L (2011) A three-stage experimental constructed wetland for treatment of domestic sewage: First 2 years of operation. Ecological Engineering 37:90-98.

Xinshan S, Qin L, Denghua Y (2010) Nutrient removal by hybrid subsurface flow constructed wetlands for high concentration ammonia nitrogen wastewater. Procedia Environmental Sciences 2:1461-1468. 